\title{
Research and Suggestions on the Reasons of Employment Difficulties of Undergraduate Students and Junior College Students
}

\begin{abstract}
Yanmin $\mathrm{Wu}^{1, *}$
${ }^{1}$ New York University, New York, United States 10003

*Corresponding author. Email: julieymwu@gmail.com

ABSTRACT

The employment difficulty of college students has become a "problem that cannot be ignored". Although many new graduates are struggling to find a satisfying job and many manufacturing job opportunities still need young people's blood to fill, it seems that many people are reluctant to take up such jobs, even if they cannot find work in other fields. Regardless of the education quality gap and benchmark for entrance for universities and junior colleges, undergraduates do not have a higher employment rate than that of junior college students. Thus, the paper aims to discuss the recent employment situation of undergraduates and junior college graduates, and to further analyze the reasons behind the difference between the two situations. Based on the collection and analysis of public information/data, combined with the method of literature review, this paper indicates that reasons behind the employment difficulties are rather multivariate, which includes but not limit to the imbalanced market demand, personal psychological factor and recent policies. Vocational education enhancement could be one of the solutions to the essential issues.
\end{abstract}

Keywords: Employment, comprehensive universities, junior college, job discrimination, vocational education enhancement, higher education

\section{INTRODUCTION}

The employment situation of undergraduates has always attracted attention from sociologists, educationalists, economists, etc. The fierce competition in job searching is obvious, and the reasons behind the problem are not uniform. The topics of employment under the pandemic, and the strategies regarding strengthening undergraduates' ability to get satisfying jobs had been discussed a lot, which were relatively specific. While there is still a lack of comprehensive analysis of the employment problem. Thus, to present a comprehensive analysis, this paper will discuss the diverse reasons behind the employment difficulties for many undergraduates and possible strategic solutions. The analysis is based on public information and data from authentic institutions.

Finding a suitable and meaningful job after graduation is one of the goals for many students, and when simply getting a job becomes a tough task then there may be something wrong either in the educational system or the demand of the labor market. It's important to figure out what possible problems are there. Through finding out possible targeting solutions, this paper could help improving employment rate of both undergraduates and junior college graduates.

\section{CURRENT EMPLOYMENT DIFFERENCE OF STUDENTS FROM JUNIOR UNIVERSITY AND COMPREHENSIVE UNIVERSITY}

In a traditional sense, comprehensive universities are viewed as superior to junior universities. Many key high schools are famous for their listing rate of students who got into key comprehensive universities, and students who go to junior college are usually the ones who do not do well in general knowledge courses. Take Beijing as an example, the Gaokao 2020 benchmark for admission to traditional comprehensive universities is 400 , while the benchmark for admission to junior college is 120 [2].

It is not only the college entrance examination system that shows comprehensive universities are better than junior colleges, but the job market shows similar signs. A total of 129 Chinese companies from the Fortune Global 
500 are on the list. According to statistics, in 2018, 107 Chinese companies from the Fortune Global 500 signed contracting units with "Double First-Class" University, which means the graduates from those comprehensive universities have guaranteed headcounts to sign employment contracts with the big companies thank to the school. Guangzhou Daily Data and Digitization Research Institute (GDI Think Tank) released the "Double First Class" University Employment Matching Data for Graduates. A total of 48,120 graduates from universities with double first-class universities have entered the world's top 500 enterprises[7].

The ultimate goal of education has always been a controversial and multifaceted issue. Setting a firm foundation for kids to develop a certain skill so they could find a proper job to support themselves financially in real life is one of the most practical goals. Usually, the job opportunities for some students in comprehensive universities are promising, however, there are some unexpected results when it comes to the real employment situation. MyCOS institute posted two sets of data analyzing the status of students who graduated from comprehensive universities and junior colleges[4-5].

Table 1. 2016 2020 Junior College Graduates Employment situation after Six Month of Graduation

Unit: \%

$\begin{array}{llllll} & 2020 & 2019 & 2018 & 2017 & 2016 \\ \text { Employed } & 68.4 & 80.3 & 82 & 82.8 & 82.6 \\ \text { Freelance } & 3.6 & - & - & - & - \\ \text { Self- } & & & & & \\ \text { Employed } & 2.8 & 3.4 & 3.6 & 3.8 & 3.9 \\ \text { Army } & 0.8 & 0.6 & 0.6 & 0.5 & 0.5 \\ \text { Applied for } & & & & & \\ \text { Comprehensiv } & & & & & \\ \text { e } & & & & & \\ \text { Undergraduat } & & & & & \\ \text { e School } & 15.3 & 7.6 & 6.3 & 5.4 & 4.9 \\ \text { Unemployed } & 9.1 & 8.1 & 7.5 & 7.5 & 8.1\end{array}$

Table 2. 2016 2020 Comprehensive University Graduates Employment situation after Six Month of Graduation

Unit: \%

$\begin{array}{llllll} & 2020 & 2019 & 2018 & 2017 & 2016 \\ \text { Employed } & 67.7 & 71.9 & 73.6 & 74.4 & 75.1\end{array}$

$\begin{array}{lccccc}\text { Freelance } & 1.7 & - & - & - & - \\ \text { Self- } & & & & & \\ \text { Employed } & 1.3 & 1.6 & 1.8 & 1.9 & 2.1 \\ \text { Army } & 0.3 & 0.2 & 0.3 & 0.3 & 0.4 \\ \begin{array}{l}\text { Graduate } \\ \text { School }\end{array} & 18 & 17.4 & 16.8 & 16.4 & 15.5 \\ \begin{array}{l}\text { During } \\ \text { process of }\end{array} & & & & & \\ \begin{array}{l}\text { Applying } \\ \text { Graduate }\end{array} & & & & & \\ \text { School } & 5.8 & 4.5 & 3.3 & 2.7 & 2.3 \\ \text { Unemployed } & 5.2 & 4.4 & 4.2 & 4.3 & 4.6\end{array}$

Since 2016, the employment rate of students from junior colleges has exceeded that of comprehensive university graduates, which might because of the situation that the top students have the guaranteed headcounts for high quality jobs provided by their school network, and the tied-up employment rates indicate that regular comprehensive university students do not necessarily have an advantage in job markets comparing to junior college students.

\section{THE REASONS FOR EMPLOYMENT DIFFICULTIES OF THE JUNIOR AND COMPREHENSIVE STUDENTS}

\subsection{Major factors behind undergraduates, employment difficulties}

Although many undergraduates claim the irrelevancy between what they learned in school and what they actually do in job markets, the education quality is not the major factor here causing the undergraduates in particular to have a hard time finding a job. There are three main reasons:

The first is the imbalance demand in the labor market of comprehensive talents and technical resources. The second is the oversaturated number of undergraduates. And the third is the wrong positioning of students which drops overall quality of undergraduates.

\subsubsection{Demand imbalance of the labor market}

The ministry of education has shown that as of June 30,2020 , there are 2,740 universities and colleges in mainland china, 1,258 regular comprehensive universities and 1,482 junior colleges. The junior colleges pay more attention to cultivating students' practical skills and abilities in the professional field, while undergraduate universities pay more attention to comprehensive cognitive training which emphasizes theoretical and academic thinkings and skills [8]. 
According to Southern Finance Omni-media Corp, the need for senior technicians in China has reached 22 million. According to the data of the Manufacturing Talent Development Planning Guide, by 2025, the talent demand in the top 10 key careers of China's manufacturing industry will reach 29.857 million[9]. On the other hand, the market demand for comprehensive talents is not as urgent as the demand for skilled talents. Take a few most highly paid industries as an example: computer engineering, automation and finance, the employment competition is so fierce that there exist head hunting companies that charge people for internships from big companies. The national consensus published the undergraduate administration rate of 2021, which shows around $40 \%$ of the students can attend comprehensive undergraduate universities, and Tianjin providence has the highest rate of $73.13 \%[10]$. The number of students from comprehensive universities and junior universities is quite even, but the matching job opportunities are not so, which becomes a major reason that causes the employment rate difference.

The number of graduates from higher educational institutions which include both comprehensive universities and junior colleges increase annually. The Ministry of Education reported that the total number of college graduates in 2021 reaches 9.09 million, an increase of 350,000 year-on-year[11]. 58 informational website, the largest life information website in China, reported that among these graduates, $64 \%$ is bachelors, $28 \%$ is graduates and the rest $8 \%$ is graduated from junior college[12]

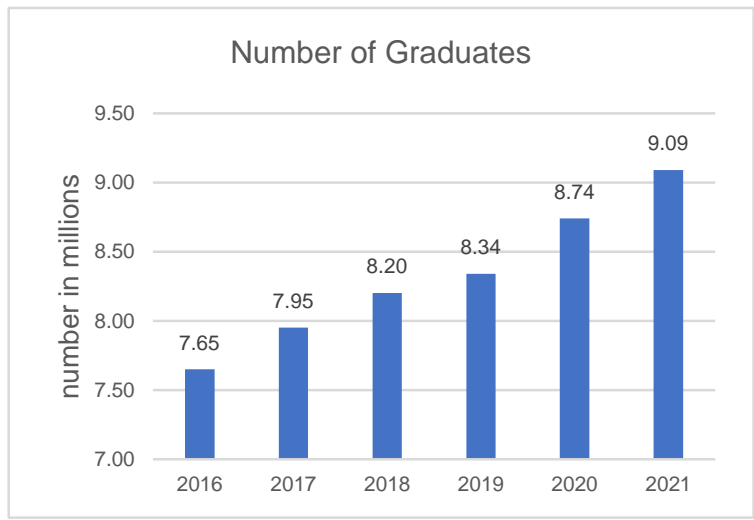

Figure 1. 2016-2021 Number of Graduates

The data reflects that undergraduates account for the majority of the graduates of 2021. Compared with the distribution of academic structure in previous years, the proportion of junior college graduates has decreased the most, and the proportion of graduate students has gradually expanded, which indicates a trend that students aim to get a higher degree, and undergraduates is no longer a rare talent resource.

\subsubsection{Oversaturated Number of People with High Education Degree}

China Employment Research Institute of the Renmin University of China and Zhaopin Recruitment jointly released the 2021 Undergraduates Employability Report. The report indicates $56.9 \%$ of recent graduates chose to work, a decrease of $18.9 \%$ compared to last year, while the number of recent graduates who chose to pursuit graduate degrees or higher increases. $9.5 \%$ of recent graduates chose to attend graduate schools domestically, and $1.9 \%$ of recent graduates chose to study abroad for a higher degree. The numbers in the form above show that the number of junior college graduates applied for comprehensive universities increases annually, and it almost doubles in 2020, partly due to the pandemic. Not only do traditional comprehensive undergraduate students want a higher degree, but also an increasing number of junior college students aim to earn a higher degree to compete with the undergraduates in job markets. Theoretically speaking, junior college students are talented with applicant skills, and there is a large demand in the market for such talents, their career path doesn't overlap with undergraduates. However, now many of them chose the traditional path. The market of undergraduates is saturated enough before the addition of junior college graduates, with the join of junior college graduates, the competition is even more fierce for all.

\subsubsection{Wrong Positioning due to Shadow Education System}

Excessive classes that kids have taken outside the school overexploited kids' potentials. The kids who took supplementary tutoring would master the materials in class better and some teachers would take their achievements as a norm, which would put all kids' parents to under pressure to send their kids to tutoring [1]. The kids are usually under great pressure because the competition inside and outside of school is fierce, and their leisure time is little because of all these tutoring. Japan has a similar situation as China, and one of their government White Paper have said that "[Our] [kids] are largely abused by their parents' over concern for diplomas and certificates, thus putting enormous pressure on young brains and probably setting them into undesirable attitude patterns as a result of a super competitive education system and a work environment that has no place for initiatives, adaptability and creativity" [1]. They were taught in the early stage of the education that their ultimate goal shall be attending an elite conventional university despite of their various talents which make them suitable for different things. Some kids are born to be craftsman, some have talents for paining, and some would be a great stylist, but they were all asked to do perfect in mathematics when they were young. 
With all the excessive tutoring, increasing number of kids would appear to be the suitable materials for higher education, while many of them were just appeared to be "smart" because of all the excessive help that they gained from outside of school. The Chinese Gaokao was supposed to pick out the most suitable kids for knowledge based higher educations, but now this mean is not as effective. Many kids who are not suitable to research driven knowledge-based educations attend conventional universities, and the wrong positioning causes the overmuch numbers of Undergraduates These branch of students are usually uncompetitive in the job market because they don't possess as good knowledge base skills as other undergraduates.

\subsection{Major factors behind junior college graduates' employment difficulties}

\subsubsection{Job Discrimination and Unequal Working Condition}

Another main reason why students are reluctant to attend junior college is that they believe the career path follow the graduation is relatively low paid and demeaning. According to the list of 100 most unemployable jobs in China that Ministry of Human Resources and Social Security of released in second quarter 2021, occupations with a large shortage in 2021 are concentrated in manufacturing and social production services [15]. Working condition in a factory is far less comfortable than that of the office. Blue collars usually work in a relatively oppressive environment where they earn salary based on the number of projects they finish. The working process is highly repetitive and tiring physically. The traditional image of a blue collar is usually a sweaty t-shirt and dusted uniform, while a classic white-collars' image is a clean white shirt with shiny black leather shoes. The conservative perspectives on blue collar and white collar could be changed if the government improve the working condition and welfare of the working class.

\subsubsection{Job Market Value Higher Education More}

The junior college graduates have great disadvantage in job markets when they try to apply jobs outside of theit technical focuses, because many companies greatly value educational level. People with higher educational degree are more likely to land with a job and have higher salaries. Near half of the recent graduates with a graduate degree have successfully landed an official job, while only around $30 \%$ of recent graduates with an undergraduate degree are successfully employed[13]. Logically, undergraduates want to pursue a higher degree because the traditional labor market requires it, and candidates with higher degrees earn more. According to Boss Zhipin Research Institute, the average salary companies offered to college level graduates in 2020 is
$5290 \mathrm{RMB} /$ month nationwide, while the salary for junior college graduates is $4250 \mathrm{RMB}$, for undergraduates is $5102 \mathrm{RMB}$, and for graduates is $7337 \mathrm{RMB}[14]$. As the treatment and welfare of employees with higher degree is so much better than that of lower degree, increasing number of students are willing to spend few more years to earn a higher degree, which causes the junior college students have been increasingly uncompetitive in the market.

\section{POSSIBLE SOLUTIONS TO THE EMPLOYMENT DIFFICULTIES}

\subsection{Clear Separation of Conventional Universities and Junior College}

The conventional universities are separated into different tiers which have different benchmarks to get into. The most valuable universities are in the first tier, and their graduates have noticeable advantages in job markets, and they are usually the ones that got talents for scientific and knowledge-based education. For example, as discussed in the beginning, 107 Chinese companies from the Fortune Global 500 signed contracts with first tier universities guarantee job opportunities for their undergraduates[7]. The rest is in an awkward position. Theoretically speaking, the undergraduates from lower tiers possess a degree certificate, but as their school is not as elite as the first-tier ones, thus they do not have as much leverage to compete the undergraduates from first tier schools for highly paid jobs. However, as they are undergraduates, they are less likely to settle with a bluecollar job or lower paid jobs which they would believe only junior college graduates are supposed to do, and they barely have the skills to do such jobs. Only a few numbers of undergraduates are from first tier universities: there are 1258 conventional universities in China, but there are only 39 " 985 " universities and 112" 211 " universities that the government is focused on constructing [18]. The lower tier universities somehow blurred the lines between junior colleges and conventional universities, because their students are not trained as well as a knowledge-based talents, meanwhile, they do not possess good practical skills as junior college students do. The educational system shall have a more accurate positioning to the students in these tiers. They are one of the reasons why the number of undergraduates is excessive. Refining the position of junior college would be a good help.

\subsection{Enhance Vocational Education}

The culture suggests that not all but most parents would try their best to support their kids to have the best conventional education so they would be able to attend a high-quality comprehensive university, because in a traditional sense a good resume and degree means a decent job with a high salary that would improve one's 
and his/her family's social status. The possible future earnings might be the obvious reason why most parents are not willing to send their kids to junior college, but the concerning quality of junior college must be the real reason behind all this.

A lot of parents are concerned that educational resources in the direction of vocational training have not received certain attention from the government. The Special Survey on Vocational Education issued by the social investigation center of China Youth Daily shows that $54.7 \%$ of parents are worried that school spirits and environment are not ideal for kids to grow, because in a conservative sense that junior college is where "bad kids" who can't go to universities gather. $51.8 \%$ of parents believe there is bias from society toward kids who attend junior college, and $50.7 \%$ of parents are concerned with overall educational quality of the school. Relatively fewer parents, $34.4 \%$, are worried that their kids would not be able to find a job[16]. The government took actions toward the enhancement of vocational education. They established policies that raise status of junior colleges. For example, 28 junior colleges were upgraded to the same standard as conventional undergraduate universities, which means that their students would have an undergraduate degree which can be helpful in the job market[17]. Such upgrades to junior colleges would attract students to follow the vocational paths as they would find it challenging to approach the conventional universities. As the government provides more welfare and social recognition to the skilled workers, parents and students would not be as anxious in terms of conventional education, which could effectively connect education with future employment.

\section{CONCLUSION}

Through the analysis of the reasons of employment difficulties of undergraduate students and junior college students, it is concluded in this paper that there is a relation among various difficulties. For the undergraduate students, imbalanced labor market lead to the scarcity of the matching employment opportunities, thus there are oversaturated number of them competing over the original number of opportunities. Parents also send many students without such talent to comprehensive universities mistakenly due to the excessive tutoring, which leads to the decline of the overall quality of undergraduate students and further makes it difficult for them to compete in the job market. The reason caused employment difficulties for junior college students is more direct: 1). job discrimination and troubling working environment drive away many students who have the specific skills, 2). Their educational degree is uncompetitive in current job market because many jobs' minimum requirement is undergraduate educational level.
It is suggested in this paper that the separation between comprehensive universities and junior colleges can be clearer through eliminating lower tiers of comprehensive universities. Meanwhile, junior graduates can be more competitive in the job market by enhancing their educational quality.

Meanwhile, this paper solely based on literature review and public data and information analysis. It lacks in-person interview with recent graduates who are actively searching for jobs, and their opinions and real life experiences could offer more perspectives on reasoning and solutions. The problem of employment is a comprehensive on-going problem, and education plays an essential role in such issue. The future work could emphasize on analysis of reformation of the education system to more accurately distribute students into different types of institutions, so they could really polish their talents and make good use of it.

\section{REFERENCES}

[1] Bray, M. (2007). The shadow education system: Private tutoring and its implications for planners. Unesco, International Institute for Educational Planning. https://bscsslm.edu.hku.hk/f/acadstaff/376/Shadow_Educatio n_System.pdf.

[2] Guo,Qian. (n.d.). 2021 Beijing Gaokao Benchmark Released. cctv.com. Retrieved September 9, 2021, from https://news.cctv.com/2021/06/26/ARTIk2oqAm8 ZJovQsSqwLsBE210626.shtml.

[3] Wang, T., \& Jiang, C. (n.d.). Is "Bachelor Degree Background" Significant: Effects of "Double FirstClass" University Bachelor Degree on the Employment Quality of the Postgraduate, China Higher Education Research, 10, 69-75. http://qikan.cqvip.com/Qikan/Article/Detail?id=71 03249215

[4] Wang, B., Ma, Y., \& Wang, L. (2021). Analysis of the status of Chinese vocational students after graduation in 2016 2020. Employment Report of China's Vocational Students in 2021. Retrieved September 10, 2021.

[5] Wang, B., Wu, Y., \& Wang, M. (2021). Analysis of the status of Chinese Undergraduates after graduation in 2020. Employment Report of China's Undergraduate Students in 2021.

[6] Hao, Longfei. "Education level, undergraduate colleges and over-education in the labor market: An analysis based on employment data of a "double first-class" construction university." Journal of Teachers College Qingdao University 007.005(2019):47-55. 
[7] Xu, J. (2019, November 12). GDI think tank released the "Double First Class" Construction College Graduates Employment Matching Data Book". Guangzhou Daily. Retrieved September 11, 2021, from https://tech.sina.com.cn/it/2019-1210/doc-iihnzhfz0684824.shtml.

[8] Cao, J. (n.d.). List of National Colleges and Universities. Ministry of Education of the People's Republic of China. Retrieved September 10, 2021, from

http://www.moe.gov.cn/jyb_xxgk/s5743/s5744/202 007/t20200709_470937.html.

[9] Editorial Department of this journal. (2017). "Manufacturing Talent Development Planning Guide". Vocational and Technical Education (03), 72 .

[10] 2021 College Entrance Examination Acceptance Rate of All Provinces Announced. sohu. (2021, August 21). Retrieved September 10, 2021, from https://www.sohu.com/a/484612497_121063611.

[11] Ministry of Education: 9.09 million college graduates nationwide this year. BJNews. (n.d.). Retrieved September 10, 2021, from https://www.bjnews.com.cn/detail/1620871884140 89.html.

[12] Five Eight focuses on the employment situation of 2021 graduates. China Economic Net. (n.d.). Retrieved September 10, 2021, from http://www.ce.cn/xwzx/gnsz/gdxw/202106/16/t202 10616_36645885.shtml.

[13] China Youth Daily. (n.d.). 2021 Undergraduates Employment Ability Survey Report released. Retrieved September 12, 2021, from https://baijiahao.baidu.com/s?id=16999315741491 $83577 \& w f r=$ spider $\&$ for $=$ pc.

[14] zhaopin.com. (2020, September 14). Employment report for college students in the fall of 2020.

[15] He, Yuran. (n.d.). Ranking of the 100 occupations with the "most shortage of employees" in the second quarter of 2021. gov.cn. Retrieved September 12, 2021, from http://www.gov.cn/xinwen/202107/22/content_5626620.htm.

[16] Liu, J. (n.d.). $66.7 \%$ of the Interviewed Parents can Accept their children to attend Vocational College. edu.china.com. Retrieved September 12, 2021, from http://edu.china.com.cn/202104/30/content_77454513.htm.

[17] Notice of the People's Government of Guangxi Zhuang Autonomous Region on the Establishment of Guangxi Agricultural Vocational and Technical University. gxzf.gov. (n.d.). Retrieved September
12,2021 ,from

http://www.gxzf.gov.cn/zfwj/zxwj/t9582579.shtml.

[18] Q\&A on 985211 School List. moe.gov. (2019, November 18). Retrieved September 28, 2021, from http://www.moe.gov.cn/jyb_hygq/hygq_zczx/moe_ 1346/moe_1366/201911/t20191128_409940.html. 